\title{
IMPLEMENTASI SISTEM PAKAR UNTUK MENDIAGNOSA PENYAKIT DENGAN GEJALA DEMAM MENGGUNAKAN METODE CERTAINTY FACTOR
}

\author{
AdiKurniadi $^{1)}$, Sismarwiyanti ${ }^{2}$ \\ Sistem Informasi, STMIK Bina Nusantara Jaya Lubuklinggau \\ Jl. Yos Sudarso No.97 A Kel. Jawa Kanan, Kota Lubuklinggau, Sumatera Selatan \\ adi27kurniadi@gmail.com ${ }^{1)}$, sisma.arsyah@gmail.com ${ }^{2)}$
}

\begin{abstract}
The expert system for diagnosing diseases with symptoms of fever is a system that will be designed as a tool to diagnose diseases with predetermined symptoms with a dynamic knowledge base. Expert systems are computer systems that can do reasoning from an expert with expertise in a particular field. The system that will be built to diagnose diseases with symptoms of fever will use the Certainty Factor method. This method will provide the possibility of the disease experienced and the percentage of beliefs. The stage of this expert system development begins with acquiring knowledge from doctors who are experts in the field of fever symptoms and then building a knowledge base and providing Certainty Factor values for each symptom associated with fever symptoms. In the final stage, the system will provide information about the possibility of the disease experienced based on the percentage of beliefs and the value of beliefs given by the user in answering questions during the consultation session when using the system. The system built will be implemented at the Megang Sakti Health Center to facilitate doctors in diagnosing diseases.
\end{abstract}

Keywords : expert system, Certainty Factor, Fever

\begin{abstract}
Abstrak
Sistem pakar untuk mendiagnosa penyakit dengan gejala demam merupakan sistem yang akan dirancang sebagai alat bantu untuk mendiagnosa penyakit dengan gejala yang telah ditentukan dengan basis pengetahuan yang dinamis. Sistem pakar merupakan sistem komputer yang dapat melakukan penalaran dari seorang pakar dengan keahlian pada suatu bidang tertentu. Sistem yang akan dibangun untuk mendiagnosa penyakit dengan gejala demam, akan mengguanakan metode Certainty Factor. Metode ini diantaraya akan memberikan kemungkinan penyakit yang dialami dan prosentase keyakinan. Tahapan pembangunan sistem pakar ini dimulai dengan mengakuisisi pengetahuan dari dokter yang ahli dalam bidang gejala demam kemudian membangun basis pengetahuan dan memberikan nilai Certainty Factor pada setiap gejala yang terkait dengan penyakit gejala demam. Pada tahapan akhir, sistem akan memberikan informasi mengenai kemungkinan penyakit yang dialami berdasarkan persentase keyakinan serta nilai keyakinan yang diberikan oleh user dalam menjawab pertanyaan selama sesi konsultasi ketika menggunakan sistem. Sistem yang dibangun akan diimplementasikan di Puskesmas Megang Sakti guna untuk mempermudah dokter dalam mendiagosa penyakit.
\end{abstract}

Kata kunci : Sistem Pakar, Certainty Factor, Demam

\section{Pendahuluan}

\section{Latar Belakang}

Seiring perkembangan teknologi yang sangat pesat, dalam bidang kedokteran saat ini telah menggunakan sistem untuk membantu dalam meningkatkan pelayanan terhadap masyarakat seperti sistem pakar misalnya. Sistem pakar merupakan suatu program komputer yang dirancang untuk mengambil keputusan yang diambil oleh seorang atau beberapa pakar. Pembuatan sistem pakar ini mengkombinasikan antara kaidah-kaidah penarikan kesimpulan (inference rules) dengan basis pengetahuan yang diberikan oleh pakar dalam bidang tertentu. Dari kedua kombinasi itulah yang akan diimplementasikan kedalam komputer dan akan digunakan untuk pengambilan keputusan dalam menyelesaikan permasalahan tertentu.

Salah satu permasalahan yang ada di Puskesmas Megang Sakti adalah terjadinya ketidak seimbangan antara dokter dan pasien. Kekurangan dokter akan membuat dokter kewalahan dalam mendiagnosa penyakit tertentu contohya penyakit dengan gejala demam. Penanganan medis menjadi lambat dan dapat mengakibatkan resiko kematian. Demam merupakan respon terhadap tubuh 
disebabkan adanya keadaan masuknya mikroorganisme dapat berupa virus, bakteri, parasit, maupun jamur yang disebut infeksi.[1] Demam juga menimbulkan kecemasan, fobia, dan stres tersendiri bagi setiap orang. Demam bukan penyakit, tetapi merupakan pertanda adanya penyakit atau benda asing dalam darah.

Dalam penanganan demam sebaiknya tidak hanya fokus pada tingginya suhu badan, tetapi juga perlu dilhat gejala-gejala lain pada demam. Penanganannya pun dapata dilakukan dengan tindakan farmakologis atau tindakan non farmakologis bisa juga kombinasi keduanya. [2] Tindakan farmakologis dilakukan dengan memberikan obat antipiretik sedangkan tindakan non farmakologis yaitu tindakan tambahan dalam menurunkan panas setelah pemberian obat antipiretik. Agar penanganan penyakit dengan gejala demam lebih efektif dan dapat mempermudah kinerja dokter, maka diperlukan sebuah sistem yang dapat dimanfaatkan untuk membantu dalam mendiagnosa sebuah penyakit, terutama penyakit dengan gejala demam.

Pembuatan sistem pakar untuk mendiagnosa penyakit dengan gejala demam ini menggunakan metodeCertainty Factor. Metodeini diantaranya akan memberikan informasi tentang kemungkinan penyakit yang dialami, persentase keyakinan dan solusi pengobatan. Tahapan pembangunan sistem pakar ini dimulai dengan mengakuisisi pengetahuan dari dokter ahli penyakit dengan gejala demam kemudian membangun basis pengetahuan dan memberikan nilai Certainty Factor pada setiap gejala yang terkait dengan penyakit gejala demam.

\section{Tinjauan Pustaka}

\subsection{Definisi Sistem Pakar}

Sistem Pakar adalah kecerdasan buatan berbasis komputer yang menggunakan knowledge (pengetahuan) dan prosedur inferensi untuk menyelesaikan masalah yang cukup sulit sehingga membutuhkan tenaga ahli untuk menyelesaikan.[3]

\subsection{Definisi Demam}

Demam merupakan suatu keadaan suhu tubuh diatas normal diakibatkan oleh peningkatan pusat pengatur suhu di hipotalamus. Keadaan ini terjadi pada anak sebagian besar karena perubahan pada pusat panas (termoreguslasi) di hipotalamus. [2]

\subsection{DefinisiCertainty Factor}

Faktor Kepastian (certainty factor) menyatakan kepercayaan dalam suau peristiwa didasarkan bukti atau penilaian pakar. Certainty Factor menggunakan suatu nilai untuk mengasumsikan derajat keyakinan seorang pakar terhadap suatu data.[4]

Adapun rumus utuk menentukan Certainty Factor :

$\mathrm{CF}[\mathrm{H}, \mathrm{E}]=\mathrm{MB}[\mathrm{H}, \mathrm{E}]-\mathrm{MD}\left[\mathrm{H}^{\prime} \mathrm{E}\right]$

Keterangan :

$\mathrm{CF}(\mathrm{H}, \mathrm{E})=$ certainty factor hipotesa yang dipengaruhi oleh edivice e diketahui depengaruhi dengan pasti.

$\mathrm{MB}(\mathrm{H}, \mathrm{E})=$ measure of belife terhadap hipotesa $\mathrm{H}$, jika diberikan edivance $\mathrm{E}(\operatorname{antara} 0$ dan 1$)$

$\mathrm{MD}(\mathrm{H}, \mathrm{E})=$ measure of disbelife terhadap evidebce $\mathrm{H}$, jika diberikan edivance $\mathrm{E}$ (antara 0 dan 1 ) tunggal

Certainty Factor untuk kaidah premis

$$
\left(\mathrm{CF}[\mathrm{H}, \mathrm{E}]_{1}=\mathrm{CF}[\mathrm{H}] * \mathrm{CF}[\mathrm{E}]\right.
$$

Certainty Factor unutk kaidah dengan kesimpulan yang serupa (similary conclude rules:

$$
\begin{aligned}
& \text { CFCOMBINECF[H,E }] 1,2=\mathrm{CF}[\mathrm{H}, \mathrm{E}] 1+\mathrm{CF}[\mathrm{H}, \mathrm{E}] 2 \\
& *[1-\mathrm{CF}[\mathrm{H}, \mathrm{E} 1]
\end{aligned}
$$

CfcombineCF[H,E $]$ okls3 $=\mathrm{CF}[\mathrm{H}, \mathrm{E}] \mathrm{old}+\mathrm{CF}[\mathrm{H}, \mathrm{E}] 3$
$*(1-\mathrm{CF}[\mathrm{H}, \mathrm{E}]$ old $]$

Suatu sistem pakar seringkali memliki kaidah dari suatu dan terdiri dari beberapa premis yang dihubungkan dengan $A N D$ atau $O R$. Pengetahuan mengenai premis dapat juga tidak pasti, hal ini dikarenakan besarnya nilai (value) $\mathrm{CF}$ yang diberikan oleh pasien saat menjawab pertanyaan sistem atas premis (gejala) yang dialami pasien atau dapat juga dari nilai CF hipotesa.

\section{Metodologi Penelitian}

\subsection{Metode Pengembangan Sistem}

Dalam penelitian ini penulis menggunakan metode pengembangan sistem model prototyping. Model prototipe (prototyping model) digunakan untuk menyambungkan ketidakpahaman pelanggan tentang teknis dan memperjelas spesifikasi kebutuhan pelanggan kepada pengembang perangkat lunak (software). [5] Model prototipe dinilai dari mengumpulkan data kebutuhan pelanggan sebagai bahan perangkat lunak yang 
akan dibuat. Program prototipe merupakan program yang belum jadi namun menyediakan tampilan dengan simulasi alur perangkat lunak yang tampak seperti sudah jadi. Prototipe ini kemudian dievaluasi oleh pelanggan sampai ditemukan spesifikasi yang sesuai dengan keinginannya. Adapun gambaran dari model prototipe sebagai berikut pada gambar 1 .

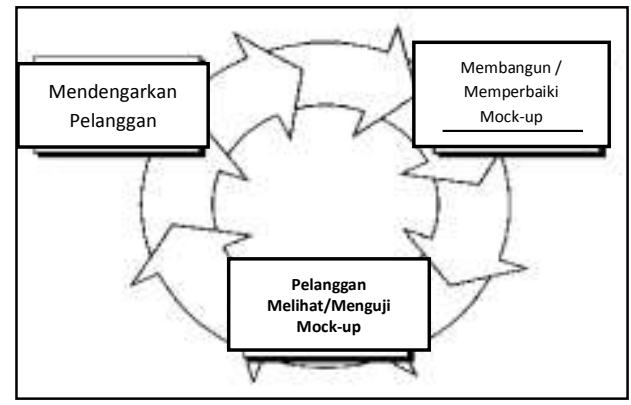

Gambar 1. Prototyping model

Tahapan-tahapan dalam prototyping model dapat dijelaskan sebagai berikut :

1) Pengumpulan informasi yang digunakan untuk pengambilan data dan informasi yang diperlukan dalam proses membangun aplikasi yang akan dibuat.

2) Membangun/memperbaiki mock-up prototipe dilakukan sebagai pengembangan hasil dari pengumpulan informasi serta memperbaiki hasil dari prototipe yang telah selesai dibangun.

3) Tahap berikutnya, setelah tahap diatas yaitu menguji hasil prototipe dengan pengujian hasil dari pembangunan prototipe. Demikian dilakukan agar tidak adanya kesalahan yang tidak diperhitungakan sebelumnya.

4) Proses pada prototipe ini prosesnya berulang jika hasil belum memuaskan. Jika hasil sudah memuaskan tahap pengujian prototipe selesai

\subsection{Metode Pengumpulan Data}

Metode pengumpulan data merupakan teknik atau cara yang dilakukan untuk mengumpulkan data. Dalam melakukan penelitian ini, penulis menggunakan beberapa metode yang digunakan untuk mengumpulkan data, adapun metode yang digunakan sebagai berikut :

\section{1) Observasi}

Penulis melakukan observasi secara langgsung di Puskesmas Megang Sakti untuk mencatat segala proses yang terjadi yang dapat menjadi penunjang dalam proses penelitian. Dari hasil observasi penulis menemukan masalah yang terdapat pada Puskesmas Megang Sakti yaitu, terjadinya ketidak seimbangan antara pasien dengan dokter sehingga proses mendiagnosa penyakit terutama penyakit dengan gejala demam menjadi lambat.

\section{2) Wawancara}

Wawancara merupakan teknik pengumpulan data melalui tatap muka dan tanya jawab secara langsung antara pengumpul data dan sumber data atau narasumber. Dalam penelitian ini penulis melakukan wawancara secara langsung kepada dokter yang ahli dalam bidang penyakit dengan gejala demam pada Puskesmas Megang Sakti, mengenai bagaimana proses mendiagnosa penyakit dan gejala-gejala penyakit pada penyakit dengan gejala demam.

\section{3) Studi Pustaka}

Studi pustaka merupakan teknik mengumpulkan data dengan mencari informasi melalui buku, jurnal dan literatur lainnya yang mendukung proses penelitian. Pada penelitian ini penulis menggunakan jurnal dan buku yang berkaitan dengan penelitian untuk mendapatkan data-data pendukung dalam proses penelitian mengenai penyakit dengan gejala demam.

\section{1) Use Case admin}

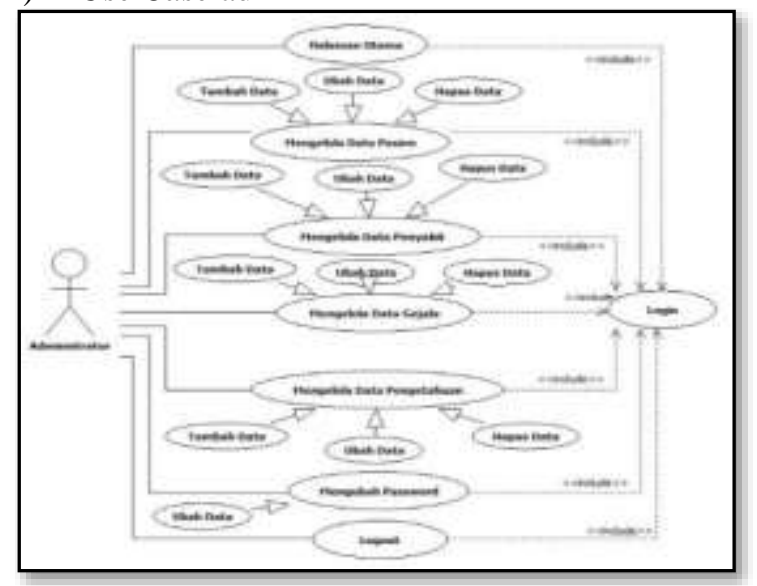

Gambar 2. Halaman Use Case admin

Gambar diatas merupakan use case diagram admin. Pada saat admin akan melakukan pengolahan data seperti data user, data gejala, data pengetahuan, dan data penyakit admin harus malakukan login dahulu. Admin juga dapat mengubah data bila ada perubahan data.

\section{2) Activity Diagram Admin}




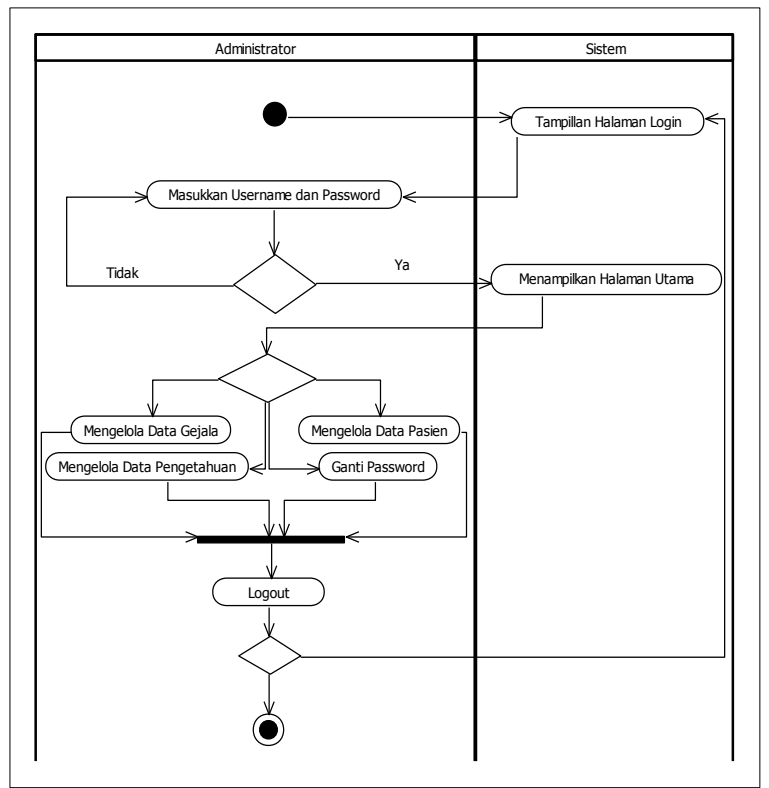

Gambar 3. Halaman Activity Diagram Admin

3) Sequence Diagram Tambah Data Pengetahuan

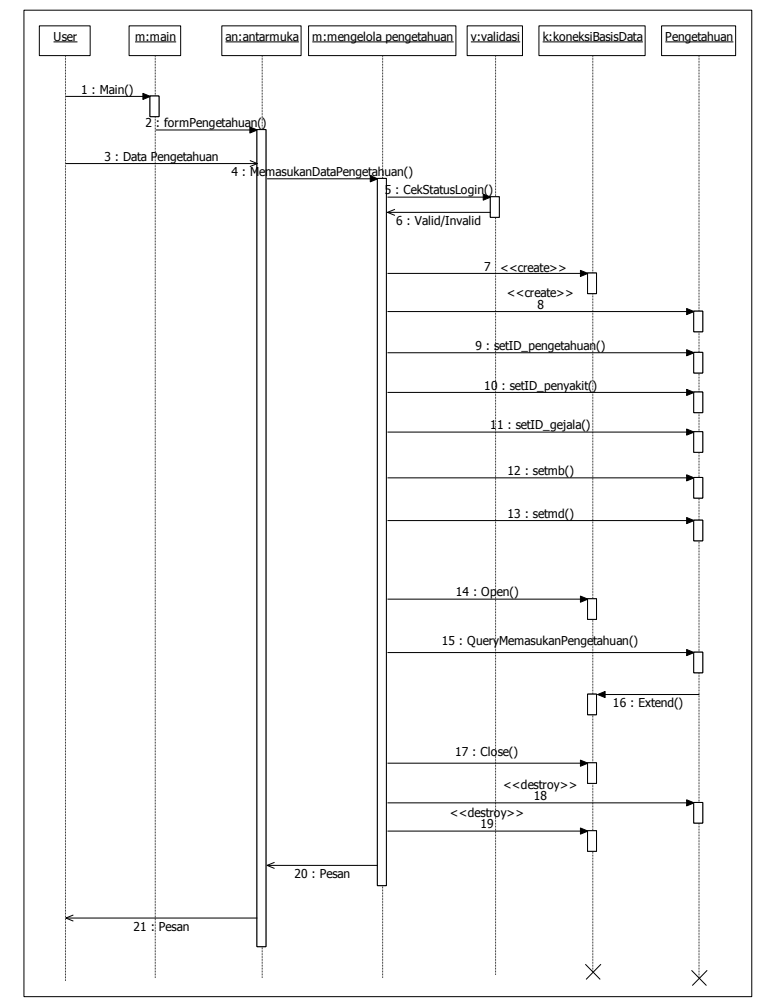

Gambar 4. Halaman Sequence diagram Tambah Data Pengetahuan

4) Class Diagram

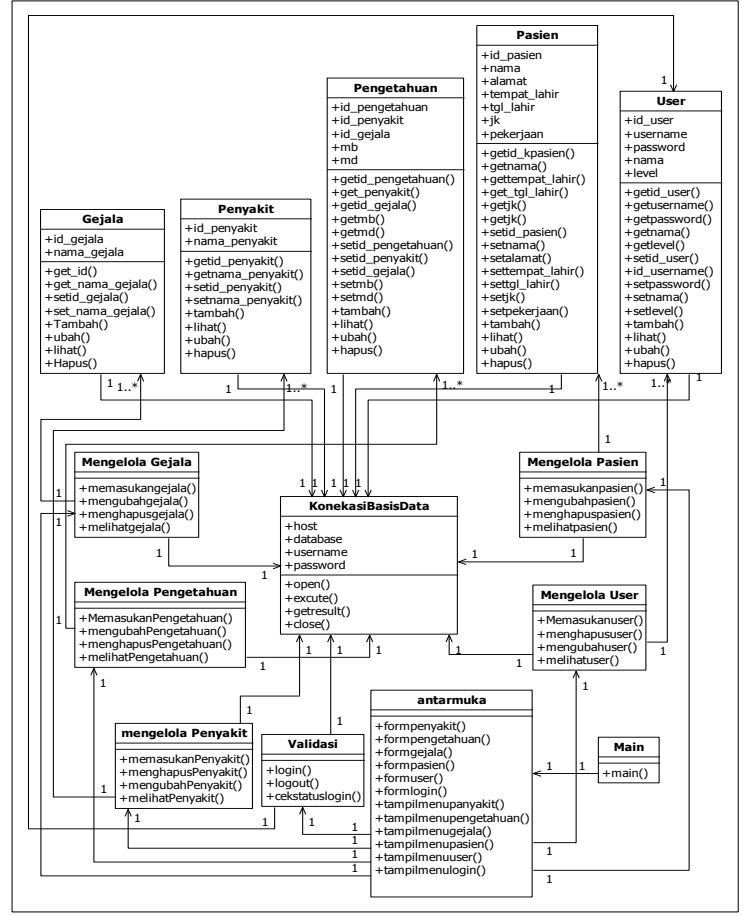

Gambar 5. Halaman Class Diagram

\section{Hasil Dan Pembahasan}

\subsection{Hasil Implementasi}

1) Halaman Login

Login digunakan untuk masuk kehalaman sistem sesuai dengan level yang telah ditentukan

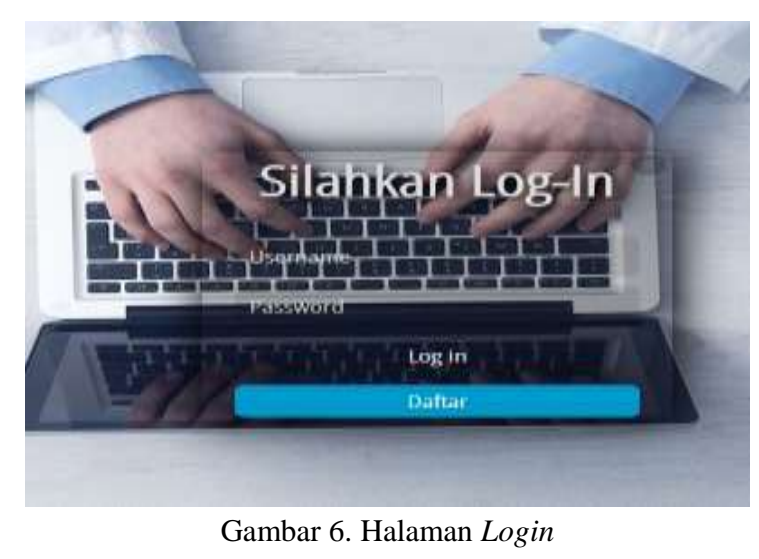

2) Halaman Pasien

Merupakan halaman yang digunakan untuk menampilkan data-data pasien yang telah disimpan ke dalam database. Halaman ini hanya dapat diakses oleh admin. Pada halaman ini admin dapat melakukan ubah tambah dan hapus data. 


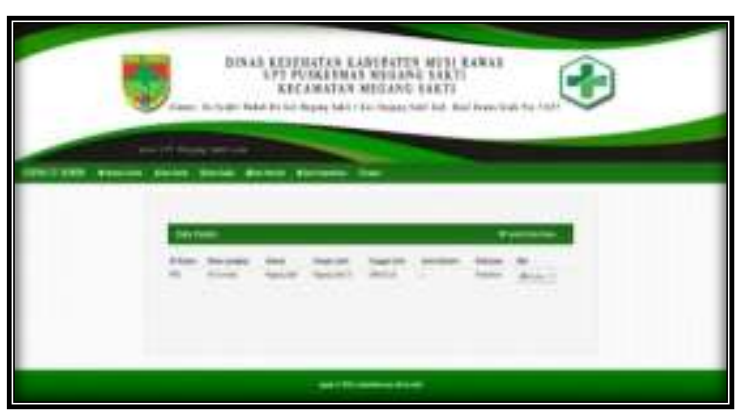

Gambar 7. Halaman Pasien

3) Halaman Data Gejala

Halaman data gejala merupakan halaman yang digunakan untuk menampilkan data-data gejala yang telah disimpan di dalam database. Pada halaman ini admin dapat melakukan ubah, hapus dan tambah. Halaman ini hanya dapat diakses oleh admin.

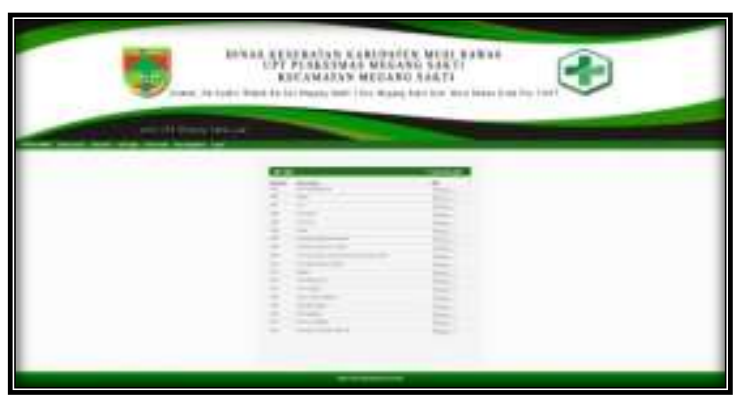

Gambar 8. Halaman Data Gejala

\section{4) Halaman Data Penyakit}

Halaman data penyakit merupakan halaman yang digunakan untuk menampilkan data-data penyakit yang telah di simpan di dalam database. Pada halaman ini admin dapat melakukan aksi ubah, hapus dan tambah. Halaman ini hanya dapat diakses oleh admin.

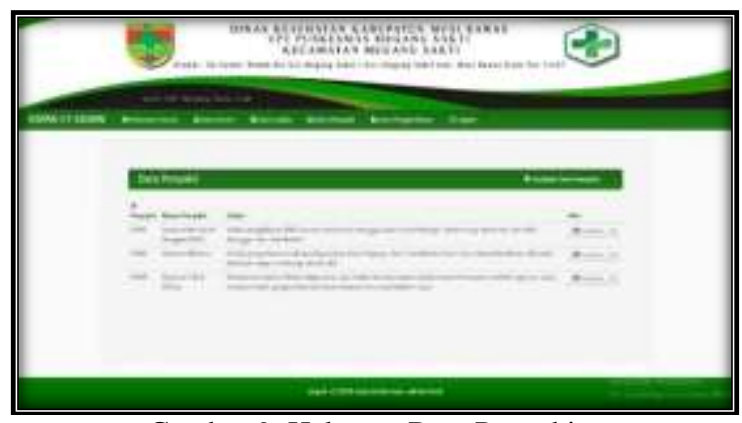

Gambar 9. Halaman Data Penyakit

5) Halaman Data Pengetahuan

Halaman data pengetahuan merupakan halaman yang digunakan untuk menampilkan data-data pengetahuan yang telah di simpan di dalam database. Pada halaman ini admin dapat melakukan aksi ubah, hapus datn tambah. Halaman ini hanya dapat diakses oleh admin.

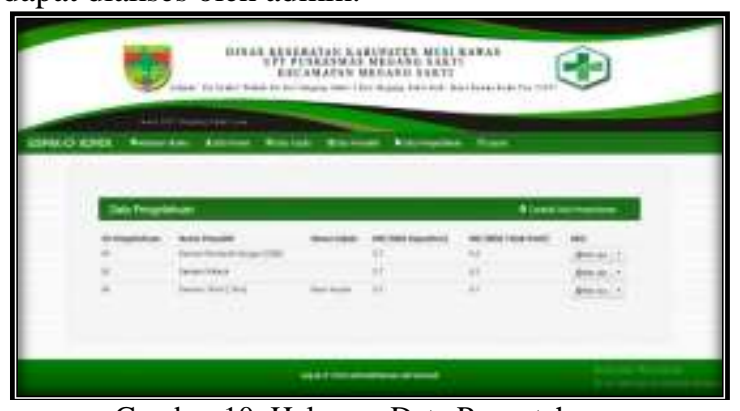

Gambar 10. Halaman Data Pengetahuan

6) Halaman Analisis

Halaman analisis merupakan halaman yang digunakan oleh pasien untuk mengetahui penyakit apa yang sedang diderita oleh pasien terhadapa gejala-gejala yang dirasakannya. Pada halaman ini proses analisis diawali dengan pasien memilih gejala-gejala yang dirasakannya, kemudian pasien memilih proses maka sistem akan otomatis memproses data gejala yang dipilih oleh pasien untuk dianalisis dan akan diketahui hasil berupa nama pasien, nilai dari penyakit yang dialami, nama penyakit dan solusi dari penyakit tersebut.

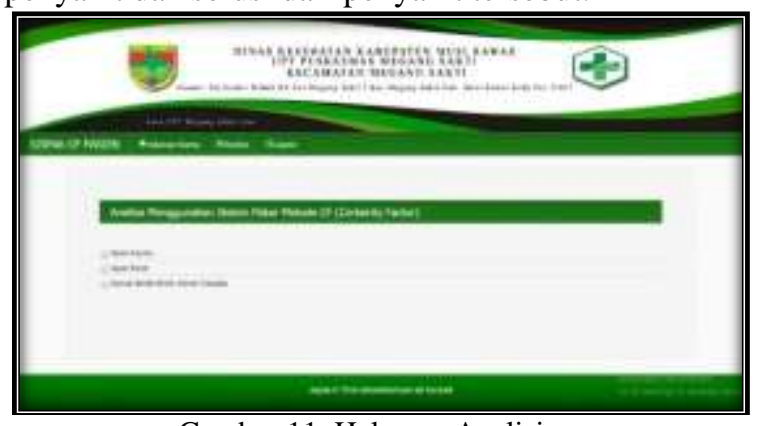

Gambar 11. Halaman Analisis

\section{7) Halaman Hasil Proses Metode Certainty Factor}

Halaman hasil proses metode certainty factor merupakan halaman selanjutnya dari proses analisis setalah pasien memilih gejala-gejala yang dirasakannya. Pada halaman ini pasien akan mengetahui apa penyakit yang dideritanya. 


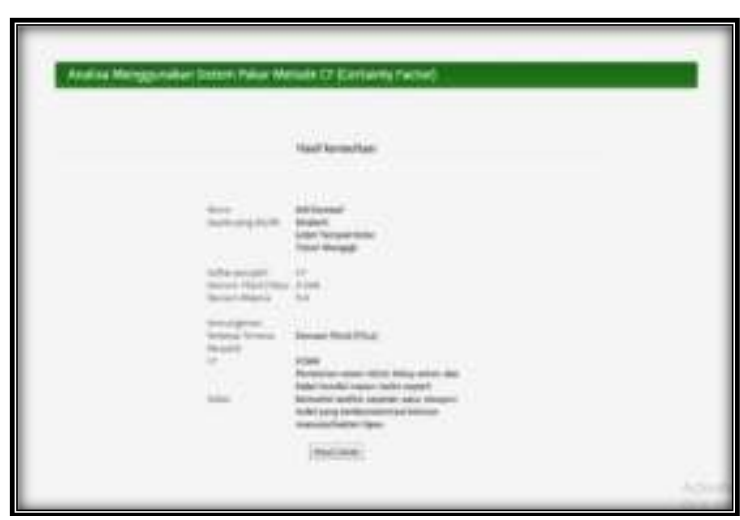

Gambar 12. Halaman Proses Certainty factor

4.2. Pembahasan Hasil

Dari hasil penelitian yang telah dilakukan maka penulis akan menguraikan hasil perhitunga dari metode certianty factor. Berikut perhitungan sistem pakar diagnosa penyakit dengan gejala demam menggunakan sistem pakar:

Gejala yang dipilih:

a) Sembelit

b) Lidah Tampak Kotor

c) Tubuh Menggil

d) Denyut Jantung Melemah

e) Penyebaran Flek Merah Pada Kulit

Rumus yang digunakan untuk perhitungan ini adalah:

\section{COMBINECF[H,E]1,2= CF[H,E $11+\mathrm{CF}[\mathrm{H}, \mathrm{E}] 2 *$ [1-CF[H,E1]}

Proses 1, merupakan proses menentukan mb lama dan md lama yang didapatkan dari nilai gejala pertama (simbelit) berikut nilainya:

Mblama $=0.6$

Mdlama $=0.2$

Proses 2, merupakan proses perhitungan kombinasi antara gejala pertama dan gejala kedua ini, pada gejala kedua nilai dijadikan mb baru dan md baru. Setelah itu akan dihitung menggunakan rumus seperti diatas dibawah ini merupakan proses perhitungan kombinasi antara gejala 1 dan gejala 2 : Mbbaru $=0.8$

Mdbaru $=0.2$

Mbsementara $=$ mblama + mbbaru $*$ (1mblama)

$$
\begin{aligned}
& =0.6+0.8 *(1-0.6) \\
& =0.92 \\
\text { Mbsementara } & =\text { mdlama }+ \text { mdbaru*(1-mdlama }) \\
& =0.2+0.2 *(1-0.2) \\
& =0.36
\end{aligned}
$$

Proses 3, setelah perhitungan diatas mendapatkan hasil maka hasil tersbut dikatakan sebagai mb dan md sementara karena akan di hitung kembali dan dikombinasikan dengan gejala ke tiga, sedangka nilai pada gejala ke tiga ini disebut dengan mb dan md baru, dibawah ini merupakan proses perhitungan kombinasi antara hasil yang didapat dari perhitungan pada proses ke dua dan ke tiga:

Mblama $=$ mbsementara $=0.92$

Mdlama $=$ mdsementara $=0.36$

Mbbaru $=0.9$

Mdbaru $=0.1$

Mbsementara = mblama + mbbaru* $(1-$ mblama $)$ $=0.92+0.9(1-0.92)$ $=0.992$

Mdsementara = mdlama + mdbaru* $(1-$ mdlama $)$ $=0.36+0.1(1-0.36)$ $=0.424$

Proses 4, setelah perhitungan diatas mendapatkan hasil maka hasil tersbut dikatakan sebagai mb dan md sementara karena akan di hitung kembali dan dikombinasikan dengan gejala ke empat, sedangka nilai pada gejala ke empat ini disebut dengan mb dan md baru, dibawah ini merupakan proses perhitungan kombinasi antara hasil yang didapat dari perhitungan pada proses ke tiga dan ke keempat:

Mblama $=$ mbsementara $=0.992$

Mdlama $=$ mdsementara $=0.424$

Mbbaru $=0.7$

Mdbaru $=0.2$

Mbsementara = mblama + mbbaru* $(1$-mblama $)$ $=0.992+0.7 *(1-0.992)$

$=0.9976$

Mdsementara $=$ mdlama + mdbaru*(1-mdlama $)$ $=0.424+0.2 *(1-0.424)$ $=0.5392$

Proses 5, setelah perhitungan diatas mendapatkan hasil maka hasil tersbut dikatakan sebagai mb dan md sementara karena akan di hitung kembali dan dikombinasikan dengan gejala ke lima, sedangka nilai pada gejala ke tiga ini disebut dengan mb dan md baru, dibawah ini merupakan proses perhitungan kombinasi antara hasil yang didapat dari perhitungan pada proses ke empat dan ke lima: Mblama $=$ mbsementara $=0.9976$

Mdlama $=$ mdsementara $=0.5392$

Mbbaru $=0.8$

Mdbaru $=0.1$

Mbsementara = mblama + mbbaru* $(1-$ mblama $)$

$=0.9976+0.8 *(1-0.9976)$

$=0.9995$

Mdsementara $=$ mdlama + mbbaru* $(1-$ mdlama $)$

$=0.5392+0.1 *(1-0.5392)$

$=0.58528$

Jurnal Ilmiah Binary STMIK Bina Nusantara Jaya

Vol. 01 No. 01 Tahun 2019, ISSN : 2657- 2117 
Setelah mendapat kan hasil, maka proses akhir yaitu menentukan penyakit yang diderita oleh pasien, yaitu dengan menggunakan rumus :

\section{$\mathrm{CF}[\mathrm{H}, \mathrm{E}]_{1}=\mathrm{CF}[\mathrm{H}]-\mathrm{CF}[\mathrm{E}]$}

Nilai Mbsementara dan Md sementara didapat dari hasil perhitungan kombinasi dari gejala pertama samapai gejala terakhir, setelah itu akan dihitung menggunakan rumus diata untuk mengetahui penyakit yang diderita oleh pasien, berikut contoh perhitungannya:

$$
\begin{aligned}
& \mathrm{Mb}=\text { mbsementara }=0.99952 \\
& \begin{aligned}
\mathrm{Md}=\text { mdsementara }=0.58528 \\
\mathrm{Cf} \quad=\text { mb-md } \\
\quad=0.99952-0.8528 \\
\quad=0.41424
\end{aligned}
\end{aligned}
$$

Setelah hasil perhitungan didapatkan maka diketahui bahwasannya pasien menderita penyakit Demam Tifoid (Tifus). Cara menentukan penyakit yaitu dengan menghitung dari setiap gejala yang dipilih, misalkan gejala yang dipilih terdapat pada penyakit DBD maka akan dihitung telebih dahulu kemudian akan didapatkan hasil, setelah itu pada penyakit malaria ada juga gejala yang dipilih kemudaian akan dihitung menggunakan proses yang sama, setelah itu pada penyakit Demam Tifoid akan dihitung juga menggunakan proses yang sama. Setelah semua penyait dihitung akan didapatkan hasil dan hasil perhtiungan di bandingkan dengan penyakit lain nanti akan diketahui penyakit mana yang mempunyai nilai terbesar

\section{Kesimpulan}

\subsection{Simpulan}

Dari hasil penelitian yang telah dilakukan penulis di Puskesmas Megang Sakti maka dapat ditarik kesimpulan:

1) Penelitian ini menghasilkan sebuah sistem pakar dengan menggunakan metode Certainty Factor (CF).

2) Sistem yang dibuat saat ini hanya dapat mendiagnosa 3 (tiga) penyakit yaitu, Demam Berdarah Dengue (DBD), Demam Tifoid (Tifus) dan Demam Malaria.

3) Gejala yang terdapat pada sistem yang telah dibuat ada 18 gejala yaitu, ada tanda-tanda syok, muntah, mual, nyeri kepala, nyeri perut, lemah, bercak bintik-bintik merah, pendarahan pada gusi/mimisan, kulit teraba dingi terutama diujung-ujung jari, nyeri pada sendi tubuh, simbelit, lidah tampak kotor, tubuh menggil, denyut jantung lemah, tidak nafsu makan, yeri punggung, nyeri otot, dan penyebaran vlek merah pada kulit.

\subsection{Saran}

Hasil penelitian di Puskesmas Megang Sakti adalah Sistem Pakar. Sistem yang telah dibuat mempunyai banyak kelemahan. Oleh karea itu bagi peneliti selanjutnya yang akan mengembangkan sistem ini, nantinya diharapkan memperbaiki beberapa kekurangan dari sistem ini. Berikut saran yang diberikan oleh penulis:

1) Sistem ini hanya dapat mendiagnosa 3 (tiga) penyakit, diharapkan bagi pengembang sistem selanjutnya dapat mendiagnosa segala penyakit yang diawali dengan gejala demam.

2) Sistem ini diharapakan dapat dikembangkan menjadi aplikasi berbasis android.

\section{Daftar Rujukan}

[1] S. Maharani and K. Adi, "Aplikasi Diagnosa Gejala Demam Pada Balita Menggunakan Metode Certainty Factor ( CF ) dan Jaringan Syaraf Tiruan ( JST )," vol. 01, pp. 25-29, 2013.

[2] A. Wardiyah, Setiawati, and U. Romayati, "Perbandingan Efektivitas Pemberian Kompres Hangat dan Tepid Spoge terhadap Penurunan Suhu Tubuh Anak yang Mengalami Demam di ruang Alamanda RSUD dr.H Abdul Moeloek," Kesehat. Holistik, vol. 10, no. 1, pp. 36-44, 2016.

[3] H. Sastypratiwi and F. A. Setyaningsih, "Aplikasi untuk Diagnosis Penyakit pada Anak dan Balita Menggunakan Faktor Kepastian," no. 0561, pp. 82-92, 2014.

[4] N. A. Sari, "Sistem Pakar Mendiagnosa Penyakit Demam Berdarah Menggunakan Metode Certainty Factor," Pelita Inform. Budi Darma, vol. 4, pp. 100-103, 2013.

[5] Rosa A.S and M. Shalahuddin, Rekayasa Perangkat Lunak. 2013. 
Jurnal Ilmiah Binary STMIK Bina Nusantara Jaya

Vol. 01 No. 01 Tahun 2019, ISSN : 2657-2117

8 